\title{
First isolation of Dioctophyme renale eggs from an urban environment and identification of those from animal urine
}

\author{
Primeiro isolamento de ovos de Dioctophyme renale no ambiente urbano e identificaçáo destes na \\ urina de animais
}

Soliane Carra Perera ${ }^{1 *}$; Gabriela de Almeida Capella ${ }^{1}$; Natália Berne Pinto ${ }^{1}$; Josaine Cristina da Silva Rappeti ${ }^{1}$; Gertrud Müller²; Rosaria Helena Machado Azambuja ${ }^{3}$; Claudia Giordanii ${ }^{1}$; Marlete Brum Cleff ${ }^{1}$

\author{
${ }^{1}$ Faculdade de Veterinária, Universidade Federal de Pelotas - UFPel, Pelotas, RS, Brasil \\ ${ }^{2}$ Departamento de Microbiologia e Parasitologia, Universidade Federal de Pelotas - UFPel, Pelotas, RS, Brasil \\ ${ }^{3}$ Departamento de Fitossanidade, Faculdade de Agronomia Eliseu Maciel, Universidade Federal de Pelotas - UFPel, Pelotas, RS, \\ Brasil
}

Received June 12, 2016

Accepted August 11, 2016

\begin{abstract}
Dioctophyme renale is a zoonotic parasite with worldwide distribution, although its occurrence is little known. The objective here was to evaluate the presence of parasite eggs in the environment and in the urine of dogs and cats in an urban area. Soil samples and urine were evaluated respectively by means of the Caldwell-Caldwell technique and urinalysis. Out of the 100 soil samples, $3 \%$ presented $D$. renale eggs, and out of the 43 urine samples, $18.6 \%$ were positive, including the feline samples. Thus, $D$. renale eggs are present in the urban environment, and dogs and cats are parasitized by this nematode, which therefore represents a risk to public health.
\end{abstract}

Keywords: Soil, urine, nematode, dog, cat, D. renale.

\section{Resumo}

Dioctophyme renale é um parasito zoonótico com distribuição cosmopolita, entretanto sua ocorrência é pouco conhecida. Assim, o objetivo foi avaliar a presença de ovos do parasito no ambiente e na urina de cáes e gatos de zona urbana. As amostras de solo e urina foram avaliadas, respectivamente, pela técnica de Caldwell e Caldwell e por urinálise. Das 100 amostras de solo, 3\% apresentaram ovos de D. renale, e das 43 amostras de urina, 18,6\% foram positivas, incluindo a de felino. Conclui-se que ovos de $D$. renale estão presentes no ambiente urbano, assim como os caninos e felinos apresentam-se parasitados, representando um risco para a saúde pública.

Palavras-chave: Solo, urina, nematódeo, cão, gato, D. renale.

Dioctophyme renale was first described by Goeze in 1782 (PEDRASSANI, 2009) and, despite having worldwide distribution, its incidence in some parts of the world is unknown. It is vital to obtain such data, since it gives rise to a zoonosis of public health importance. Dioctophymiasis has been reported in several species, such as ferrets (PESENTI et al., 2012), cats (PEDRASSANI et al., 2014) and dogs (STAINKI et al., 2011), as well as in humans (VENKATRAJAIAH et al., 2014). Occurrences of this parasitic infection in certain regions may be due to the high potential of these areas for water-borne transmission, and to the presence of stray dogs with unselective eating habits (KOMMERS et al., 1999; PEREIRA et al., 2006). The objective of this study was to evaluate the presence of parasite eggs in soil samples from the

*Corresponding author: Soliane Carra Perera. Faculdade de Veterinária, Universidade Federal de Pelotas - UFPel, Campus Universitário, s/n, CP 354 , CEP 96010-900, Capão do Leão, RS, Brasil. e-mail: soliane.cp@hotmail.com urban area of Pelotas, southern Brazil, and in urine samples from dogs and cats in this city.

Analysis on soil contamination by $D$. renale eggs was carried out in the region of a veterinary clinic near the center of Pelotas, a city located in the southern region of the state of Rio Grande

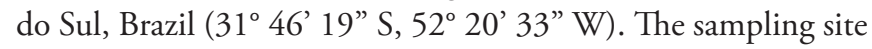
was thus defined because many animals were being diagnosed as positive for this parasite in this region. This study formed part of an extension project of the Veterinary School of the Federal University of Pelotas (UFPel).

In July and August 2015, soil sampling and analysis were performed, with evaluations at four sites within the community. This place was chosen because it is located in the central area of the city with stray dogs and cats who has been diagnosed with dioctophymiasis. At each site, $250 \mathrm{~g}$ of sandy soil were obtained from the four corners and the center, thus corresponding to 20 samples. These were then identified and stored under refrigeration. Each 
sample collected was divided into five fractions of $6 \mathrm{~g}$, thus totaling 100 samples. The material was processed in the Department of Microbiology and Parasitology (DEMP) of UFPel by means of the Caldwell-Caldwell centrifugal flotation technique in sodium dichromate (as adapted by GALLINA et al., 2011). It was analyzed under an optical microscope at $40 \mathrm{X}$ magnification to identify D. renale eggs.

Urine samples were obtained from animals at the veterinary clinic (12 samples from dogs and one from a cat), the Veterinary Hospital of UFPel (12 samples from dogs) and the Municipal Kennel of Pelotas (18 samples from dogs), thus totaling 43 samples. The collection of urine samples were made by spontaneous urination or, when necessary, by urethral probe of animals, with permission from their keepers, or from the veterinarian in the case of the Municipal Kennel. In the latter place, the animals were from different districts of the city, and were housed there for short periods on a rotating basis until their release.

The urine samples were stored in sterile vials and were kept refrigerated until analysis in DEMP-UFPel, where they were processed by means of the centrifugal sedimentation technique (LOPES et al., 2007) to identify the $D$. renale eggs. To obtain data on the animals (sex, species, breed, age and keeper), a questionnaire that was filled out at the time of sampling was used. This study was approved by the UFPel Ethics Committee (CEEA 4390/2015), and the results were analyzed using the chi-square test and frequency distribution (Statistix 9.0).

Out of the 100 soil samples, three showed $D$. renale eggs, which came from the same collection point, thus representing a positivity rate of $3 \%$. This was the first report of parasite eggs in this environment, and their presence was probably due to the presence of infected animals in this location, given that dioctophymiasis has been documented in dogs and wild animals in Pelotas (STAINKI et al, 2011; PESENTI et al, 2012; PASINATO, 2016). Moreover, the environment studied presents conditions that could favor the spread of this nematode, given its location on the banks of the Canal São Gonçalo. Regions with a high potential for water-borne transmission may favor the presence of paratenic and intermediate hosts of $D$. renale (PEREIRA et al., 2006).

To evaluate the possible presence of dioctophymiasis in animals, 43 urine samples ( 42 from dogs and one from a cat) were analyzed. Seven samples from the dogs $(16.6 \%)$ were positive for $D$. renale, and the sample from the cat was also positive (100\%), thus totaling a positivity rate of $18.6 \%$. There was no statistical difference $(p>0.05)$ in the results from the urine analyses in relation to the data on the animals (sex, breed, age and keeper), except for the species $(\mathrm{p}=0.03)$ (Table 1$)$.

The frequency of $D$. renale eggs in the urine of animals was $18.6 \%$, but it is not possible to define this as the actual frequency in Pelotas because it is just an initial study. However, other authors have demonstrated isolation frequency parasite eggs of 2\% (COLPO et al., 2007) and 14.2\% (PEDRASSANI, 2009) in the urine of dogs. In relation to the sex of the animals, the result from the present study was at odds with previous studies, in which there was higher occurrence of parasitic disease in female dogs (COTTAR et al., 2012).

The eggs identified in the urine and soil samples were elliptical and yellowish-brown, with a thick and rough wall and bipolar
Table 1. Distribution of animals parasitized by D. renale in Pelotas in terms of sex, species, breed, age and keeper.

\begin{tabular}{|c|c|c|c|}
\hline \multicolumn{2}{|c|}{ Variables } & \multirow{2}{*}{$\frac{\text { Positive }}{7}$} & \multirow{2}{*}{$\frac{\text { Negative }}{25}$} \\
\hline Ser & Male & & \\
\hline Sex & Female & 1 & 10 \\
\hline \multirow{2}{*}{ Species } & Canine & 7 & 35 \\
\hline & Feline & 1 & 0 \\
\hline \multirow{2}{*}{ Breed } & Mixed breed & 8 & 31 \\
\hline & Pit Bull & 0 & 4 \\
\hline \multirow{3}{*}{ Age } & $<1$ year & 0 & 3 \\
\hline & $1-8$ years & 8 & 30 \\
\hline & $>8$ years & 0 & 2 \\
\hline \multirow{2}{*}{ Keeper } & With & 4 & 20 \\
\hline & Without & 4 & 15 \\
\hline
\end{tabular}

buffers. Identification of $D$. renale eggs in urine is one of the most important means of diagnosing parasitic disease, and the microscopic characteristics of the eggs were in agreement with the literature (COLPO et al., 2007; PEDRASSANI, 2009).

The total number of positive urine samples (18.6\%) may have been an underestimate, given that $D$. renale eggs are only observed if the female parasite is in the kidneys of dogs and cats. It is therefore possible that the true level of contamination among animals in the study area may be higher. In addition to the fact that stray dogs inhabit local wetlands and are unselective feeders, the presence of rats (Rattus norvegicus) may be an important factor in relation to the frequency of this parasite in the study area, since rodents could act as paratenic hosts for D. renale (KOMMERS et al., 1999), and would mostly serve as a source of infection for dogs and cats.

Given the above, it can be concluded that environmental contamination by $D$. renale eggs is present in Pelotas, and that dogs and cats have become infected. These findings serve as a public health warning for the city, since dioctophymiasis is a zoonosis for which most animals do not show any specific clinical signs. Undetected infected animals may be living in close contact with other animals and with humans.

\section{References}

Colpo CB, Silva AS, Monteiro SG, Stainki DR, Camargo DG, Colpo ETB. Ocorrência de Dioctophyma renale em cães no Município de Uruguaiana - RS. Rev FZVA 2007; 14(2): 175-180.

Cottar BH, Dittrich G, Ferreira AA, Carvalho ACP, Albernaz VGP, Luz $\mathrm{MT}$, et al. Achados ultrassonográficos de cães parasitados por Dioctophyma renale - estudo retrospectivo. Vet Zootec 2012; 19(S1): 8-11.

Gallina T, Silva MAMP, Castro LLD, Wendt EW, Villela MM, Berne MEA. Presence of eggs of Toxocara spp. and hookworms in a student environment in Rio Grande do Sul, Brazil. Rev Bras Parasitol Vet 2011; 20(2): 176-177. PMid:21722496. http://dx.doi.org/10.1590/S198429612011000200016 
Kommers GD, Ilha MRS, Barros CSL. Dioctofimose em cães: 16 casos. Cienc Rural 1999; 29(3): 517-522. http://dx.doi.org/10.1590/S010384781999000300023.

Lopes STA, Biondo AW, Santos AP. Manual de patologia clínica veterinária. Santa Maria: Universidade Federal de Santa Maria; 2007.

Pasinato M. Pelotas registra casos de verme gigante do rim: Incidência da verminose em cães e gatos é considerada alta na cidade [online]. Diário Popular. Caderno Alerta, 2016 Maio 2 [cited 2016 May 9]. Available from: http://www.diariopopular.com.br/tudo/index.php?n_sistema=3056\&id_ noticia=MTExODU2\&id_area $=\mathrm{MA}==$

Pedrassani D. Aspectos morfológicos, imunológicos e epidemiológicos do Dioctophyme renale em cães no distrito de São Cristóvão, Três Barras, Santa Catarina [Tese] Jaboticabal: Universidade Paulista "Julio de Mesquita Filho"; 2009.

Pedrassani D, Wendt H, Rennau EA, Pereira ST, Wendt SBT. Dioctophyma renale Goeze, 1782 in a cat with a supernumerary kidney. Rev Bras Parasitol
Vet 2014; 23(1): 109-111. PMid:24728372. http://dx.doi.org/10.1590/ S1984-29612014018.

Pereira BJ, Girardelli GL, Trivilin LO, Lima VR, Nunes LC, Martins IVF. Ocorrência de dioctofimose em cáes do município de Cachoeiro do Itapemirim, Espírito Santo, Brasil, no período de maio a dezembro de 2004. Rev Bras Parasitol Vet 2006; 15(3): 123-125. PMid:16978477.

Pesenti TC, Mascarenhas CS, Krüger C, Sinkoc AL, Albano APN, Coimbra MAA, et al. Dioctophyma renale (Goeze, 1782) collet-meygret, 1802 (Diotophymatidae) in Galictis cuja (Molina, 1782) (Mustelidae) in Rio Grande Sul, Brazil. Neotrop Helminthol 2012; 6(2): 301-305.

Stainki DR, Pedrozo JCSR, Gaspar LFJ, Zanette RA, Silva AS, Monteiro SG. Urethral obstruction by Dioctophyma renale in puppy. Comp Clin Pathol 2011; 20(5): 535-537. http://dx.doi.org/10.1007/s00580-010-1169-0.

Venkatrajaiah N, Kalbande SH, Rao GV, Reddy VC, Reddy SH, Rao $\mathrm{PR}$, et al. Dioctophymatosis renalis in humans: first case report from India. J Assoc Physicians India 2014; 62(10): 70-73. PMid:25906531. 